\title{
Mathematics Online Learning via WhatsApp: How Effective?
}

\author{
Al Ikhlas \\ STKIP Mubammadiyah Sungai Penuh \\ alikhlas752@gmail.com
}

\begin{abstract}
This study aims to determine the effectiveness of online mathematics learning using the Whats App application on students' learning outcomes at one junior high school in Kerinci, Jambi, Indonesia. This research is quantitative descriptive research. The sample of the research was eighth-grade students. The instrument used in this study was a questionnaire and test. The hypothesis was evaluated using the one-sample t-test. This study shows that online mathematics learning using the Whats App application during the Covid-19 was ineffective in improving the students' learning outcomes.
\end{abstract}

Keywords: Mathematics Online Learning, Students' Learning Outcome, Whats App Application

\section{INTRODUCTION}

Using social media can be in the form of students asking about assignments or materials given by the teacher or the teacher informing students of essential tasks or materials that must be studied. One of the online media used in the eighth grade of SMP Negeri 7 Kerinci is social media known as WhatsApp because WhatsApp is one of the most commonly used communication applications on smartphones. Utilizing WhatsApp as an online medium is beneficial in communication activities between teachers and students and vice versa.

Prajana (2017) stated that one of the applications developed and become popular now is WhatsApp. WhatsApp is one of the mobile phone applications and web-based social networks that integrates with various applications used to communicate with other users, ranging from education, business, entertainment to many developed social networking sites. Today's applications are expected to function from social networking sites like chatting or broadcasting messages. However, more to the collaboration applications (collaboration applications) and information sharing (information sharing), more will find that the purpose of e-learning really can be exploited.

The WhatsApp application has many supporting features in it. WhatsApp features that can be used: (1) signs that the message has been successfully sent, received, or read; (2) can send documents in the form of photos, videos, audio, locations, and contacts; (3) view contact, users can see if other users have a WhatsApp account by viewing the contact from the smartphone; (4) avatar, WhatsApp user profile photo; (5) add conversation shortcuts, some chats can be added shortcuts to the home screen; (6) email conversation, can send all chat by email; (7) Forward, a feature to forward or resend messages that have been received; (8) smile icon, a large selection of emoticons such as human expressions, buildings, weather, animals, musical instruments, cars, and others; (9) voice call, to make voice calls with other users; (10) video call, in addition to voice 
calls, users can also make video calls; (11) block, to block other people's numbers; and (12) status to notify other contacts that the user is willing or not willing to chat.

Based on the description above, it can be concluded that WhatsApp can be used in welldesigned learning to understand the subject matter, discuss and increase student activity in learning, especially in learning mathematics. WhatsApp (WA) is an ordinary communication medium, not made to be a learning medium. However, many teachers use WA as a learning medium for specific reasons. Although several studies have shown the effectiveness of WA, its effectiveness still needs to be tested further. Therefore, it is necessary to test the effectiveness of using WA as a learning medium.

Since the pandemic outbreak caused by the Coronavirus in Indonesia in March 2020, the government has taken many ways to break the spread chain. Based on the Circular issued by the government on March 18, 2020, it is stated that to reduce the spread of the coronavirus. All activities carried out indoors and outdoors in all sectors are temporarily postponed. On March 24, 2020, the Minister of Education and Culture of the Republic of Indonesia issued Circular Number 4 of 2020 concerning the Implementation of Educational Policies in the Emergency Period for the Spread of Covid-19. In the Circular, it was explained that during the Covid-19 pandemic, the learning process was carried out in each other's homes through online/distance learning. Distance learning or electronics learning is a concept carried out using internet technology as a medium.

Schools have begun to change the learning strategy initially face-to-face by changing it to non-face-to-face learning, or online learning and distance learning. Various learning models that teachers can use to help students study at home. The government provides various learning applications that can be accessed and used by teachers and students.

According to Arsyad (2011), online learning media or often referred to as e-learning, is a media to support education and not as a substitute for education. The process of e-learning as a distance learning medium creates a new paradigm, namely the role of teachers who are more "facilitators" and students as "active participants" in the teaching and learning process. Therefore, teachers must create good teaching techniques and present interesting teaching materials, while students must actively participate in the learning process. Online learning is also often referred to as online learning or in the network. The utilization of online learning systems is one of the efforts that can be done to overcome problems and make it easier for students to access learning materials. Riyanda, Herlina, \& Wicaksono (2020) explained that several things that can be done during online learning (online) are communicating with each other and discussing online.

According to (Handarini \& Wulandari, 2020), adequate facilities and infrastructure are needed in online learning, such as laptops, computers, smartphones, and internet networks. These needs can be an obstacle experienced by students, especially for underprivileged students in areas where the majority of the economy is still low because not all students have facilities that can support this online learning process. In addition, the obstacles that occur in online learning are in the financing, which can overcome the limitations of hardware (hardware), software (software), and no less critical in internet accessibility (Yaumi, 2018). This problem underlies the author to find out an overview of the effectiveness of online learning on mathematics subjects in Cilegon City during the Covid-19 pandemic.

Currently, the education system is faced with a situation that demands to master distance learning media, especially during this Covid-19 outbreak. One of the efforts that can be made to 
overcome the difficulties in face-to-face learning is physical distancing rules considering the problems of time, location, distance, and cost, which are currently significant obstacles.

The importance of innovation in the form of integration with the environment refers to Hammond's digital learning ecosystem component that can accommodate the learning style, flexibility, and learning experience of learners bring positive feelings. Oktavian \& Aldya (2020) stated that online learning would be effective if applying the essential components of Laurillard that including discursive, adaptive, interactive and reflective aspects. Nevertheless, $76.07 \%$ chose the combination of online learning.

Based on the results of observations of the online mathematics learning process in the $A$ group of the eighth grade of SMP Negeri 7 Kerinci with a total of 29 students, it is known that students do not understand the material given by the teacher. This problem is because in studying mathematics, students have to think to understand learning mathematical concepts and be able to use these concepts appropriately when he has to look for answers to various math problems. In contrast, the thought process cannot be obtained from learning carried out remotely, and also, the poor network conditions in Kerinci make students unable to study well. Not all students can use applications such as Zoom Meeting or Google Classroom as used by students in big cities. one of the efforts to overcome this problem is to apply online learning using the WhatsApp application.

WhatsApp is an application for instant messaging and allows us to exchange pictures, videos, photos, voice messages and can be used for various information and discussions. Fajar \& Larasati (2022) concluded that WhatsApp was included in the effective category as a means of learning discussion. The benefits of learning to use WhatsApp are that it can help students learn anywhere, anytime, and use the material repeatedly. Based on the problems above, this study aims to determine the effectiveness of online mathematics learning using the WhatsApp application on student learning outcomes at SMP Negeri 7 Kerinci.

\section{METHOD}

This type of research is descriptive with a quantitative approach. This research method is carried out by seeking information about existing symptoms or phenomena. For this reason, the research subjects were students of the A group of the eighth grade of SMP Negeri 7 Kerinci totalling 29 students consisting of 18 males and 11 females. The choice of research subjects was carried out intentionally based on the consideration that mathematics learning activities in the A group of the eighth grade of SMP Negeri 7 Kerinci were carried out online using the WhatsApp application during the Covid-19. The independent variable in this study was online mathematics learning using the WhatsApp application. In contrast, the dependent variable in this study is the learning outcomes.

The primary data of this research is data on online mathematics learning using the WhatsApp application, which was obtained from distributing a questionnaire totalling 25 items to eighth-grade students. Questionnaire trials were conducted to determine the validity and reliability of the research questionnaire. The research instrument was tried on 30 students. As for the questionnaire validity test results, it is known that 25 items are in a valid category, and overall the questionnaire was reliable.

The measurement scale of the questionnaire is a Likert scale. Alternative answers to the questionnaire, as shown in Table 1 (Riduwan, 2010). 
Table 1. Alternative Questionnaire Answer Options

\begin{tabular}{cccc}
\hline Answer (+) & Score & Answer (-) & Score \\
\hline Strongly Disagree & 1 & Strongly Agree & 4 \\
\hline Disagree & 2 & Agree & 3 \\
\hline Agree & 3 & Disagree & 2 \\
\hline Strongly Agree & 4 & Strongly Disagree & 1 \\
\hline
\end{tabular}

Hypothesis testing using the one-sample t-test.

\section{FINDINGS}

\section{Online Mathematics Learning Activities}

The online mathematics learning using the WhatsApp application during the Covid-19 in the eighth grade of SMP Negeri 7 Kerinci consists of three sections. Firstly, the opening section. In this section, the teacher distributes learning materials and explains the procedures for online mathematics learning using the WhatsApp application through the WhatsApp group one day before the lesson is held or when learning is about to begin. Secondly, the core section. Activities at this stage include: (a) students make a summary of the learning materials that have been distributed to the class group, (b) the teacher explains the learning materials that have been distributed to the class group, (c) the teacher provides feedback on questions that students ask the teacher, (d) the teacher gives practice questions to students, (e) each student works on the practice questions given by the teacher ( $\mathrm{f}$ ) the teacher checks the results of student answers, and (g) the teacher provides feedback on the students' answers that have been checked. Lastly, the closing section. Activities at this section include: (a) with students making conclusions about learning materials, (b) teachers informing learning materials that will be studied at the next meeting.

The teacher starts the lesson by saying hello and asking the rest to be absent first, then the teacher gives a task in the form of copying the notes in the math manual, and the teacher gives a deadline for sending assignments. It can be seen there that students respond by answering greetings and filling in the attendance list. The results of the online mathematics learning questionnaire using the WhatsApp application during the Covid-19 shown in Table 2

Table 2. Results of Online Mathematics Learning Questionnaires

\begin{tabular}{ccc}
\hline \multirow{2}{*}{$\mathbf{N}$ Malid } & $\mathbf{2 9}$ \\
\cline { 2 - 3 } & Missing & $\mathbf{0}$ \\
\hline Mean & 67,52 \\
\hline Median & 69,00 \\
\hline Mode & 73,00 \\
\hline Variance & 83,83 \\
\hline Std. Deviation & 9,16 \\
\hline Minimum & 40,00 \\
\hline Maximum & 80,00 \\
\hline Sum & 1958,00
\end{tabular}


Based on Table 2, it can be concluded that learning mathematics is online using the WhatsApp application during the Covid-19 in the eighth grade of SMP Negeri 7 Kerinci was classified as good.

\section{Student Mathematics Learning Outcomes}

The mathematics learning outcomes of eighth-grade students of SMP Negeri 7 Kerinci presented in this study are the results of learning mathematics before and after online mathematics learning using the WhatsApp application during the Covid-19. Students' mathematics learning outcomes before online mathematics learning using the WhatsApp application during the Covid-19 were obtained from pretest results on number pattern material, while students' mathematics learning outcomes after online mathematics learning using the WhatsApp application during the Covid-19 were obtained from mid-semester results as a posttest. The results of students' mathematics learning before online mathematics learning using the WhatsApp application during the Covid19, as shown in Table 3.

Table 3. Students' Mathematics Learning Outcomes Before and After Online Mathematics Learning

\begin{tabular}{cccc}
\hline \multirow{2}{*}{$\mathbf{N}$} & Before & After \\
\cline { 2 - 4 } & Valid & $\mathbf{2 9}$ & $\mathbf{2 9}$ \\
\cline { 2 - 4 } & Missing & $\mathbf{0}$ & $\mathbf{0}$ \\
\hline Mean & 67,55 & 58,97 \\
\hline Median & 68,00 & 29,00 \\
\hline Mode & 67,00 & 58,00 \\
\hline Variance & 8,76 & 5,25 \\
\hline Std. Deviation & 2,96 & 2,29 \\
\hline Minimum & 62,00 & 52,00 \\
\hline Maximum & 72,00 & 62,00 \\
\hline Sum & 1929,00 & 1710,00 \\
\hline
\end{tabular}

Based on Table 3, it can be concluded that the mathematics learning outcomes of eighthgrade students before online mathematics learning using the WhatsApp application during the Covid-19 were relatively high. Furthermore, based on the average score (mean), it can also be concluded that the mathematics learning outcomes of eighth-grade students after online mathematics learning using the WhatsApp application during the Covid-19 were relatively high.

Based on the table above, it is known that the mathematics learning outcomes of eighthgrade students before online mathematics learning using the WhatsApp application during the Covid-19 were higher than the mathematics learning outcomes of eighth-grade students after online mathematics learning using the WhatsApp application during the Covid-19. In other words, online mathematics learning using the WhatsApp application during the Covid-19 was ineffective in improving the learning outcomes of eighth-grade students of SMP Negeri 7 Kerinci.

\section{Hypothesis Test Results}

The results of the one-sample t-test, as shown in Table 4. 
Table 4 Test Results One-Sample T-Test

\begin{tabular}{cccc}
\hline $\mathbf{T}$ & Df & Sig. (2-tailed) & Mean Difference \\
\hline$-25,937$ & 28 & 0,000 & $-11,03$ \\
\hline
\end{tabular}

Based on Table 4, it can be concluded that online mathematics learning using the WhatsApp application during the Covid-19 was not effective in improving the learning outcomes of eighth-grade students of SMP Negeri 7 Kerinci. The difference in the KKM score (70) with the average value of mathematics learning outcomes for eighth-grade students after online mathematics learning using the WhatsApp application during the Covid-19 (58.97) is 11.03.

\section{DISCUSSION}

Concerning learning outcomes, distance learning such as WhatsApp media is still a polemic among teachers and students because distance learning is still considered no better than conventional direct learning, especially in mathematics. Online mathematics learning using the WhatsApp application during the Covid-19 was ineffective in improving the learning outcomes of eighth-grade students of SMP Negeri 7 Kerinci. This problem is because in studying mathematics, students must think to understand the mathematical concepts being studied and use these concepts appropriately when they have to find answers to various math problems, while the thought process cannot be obtained from the learning carried out remotely.

This result aligns with the previous research, which states that WhatsApps as online learning media is less effective in achieving learning objectives. This problem is due to various factors, including the teacher's lack of a comprehensive and simple explanation, low affective and psychomotor aspects of learning, internet signals, parents' busyness, and parents' educational background (Daheri et al., 2020).

Using the WhatsApp application can help students learn anywhere, anytime, and use material repeatedly in online mathematics learning. An educator must use the WhatsApp application to strengthen student learning outcomes. The additional point of the WhatsApp application, apart from providing convenience for students who have learning difficulties, can also allow students to take control over their learning activities.

This finding is in line with Afika \& Pujiastuti (2021) that concluded that students prefer to use WhatsApp and Google Classroom applications in online learning because they already know them beforehand, so it is easy to use (Zhafira et al., 2020). However, based on the survey data, students feel that educators are still lacking in providing teaching materials, such as learning videos which are very important because they can make it easier for students to understand the material compared to just based on textbooks.

Even though the teacher, of course, always motivates children through their respective class WhatsApp groups. In this pandemic, even though learning from home uses a simple application, if there is no support and care from parents, then in our opinion, learning is still not optimal. There needs to be a synergy between schools, teachers, and parents for the best education for children.

This finding is in line with the research of Mustakim (2020) The result showed the presentation on students' who were assuming learning mathematics was very effective with online learning was $23.3 \%$, the majority of students who assumed it was effective was $46.7 \%, 20 \%$ of them assume it was nothing special, $10 \%$ assume it was not effective, and $0 \%$ assume it was very 
ineffective. It also found from the study that to enhance the quality of mathematics online learning during the covid-19 pandemic, the teachers should full fill the respondent recommendations, they are; (1) the learning should be done with video call (2) the contents should be simple; (3) minimize the learning video capacity (4) the language that used in the video should be easy to understand; (5) the content should be explained before giving the task; (6) variety task for each student; (7) the task should come with clear instructions; (8) the task should be on schedule; (9) the task should be reminded to the students; (10) reduces the task.

This change in the learning process requires teachers to change the way of teaching from direct teaching to indirect teaching. The main problem in the world of education during the Covid-19 pandemic is how to make students, even though they have to stay at home, still study. Because learning is the primary means for students to grow optimally, the online learning process is an asynchronous learning process, which is expected to continue to be comfortable and enjoyable for all school members, especially teachers and students.

The use of media in learning is a supporting tool that can increase the efficiency and effectiveness of successful learning, and specially designed and tailored media can contribute to the effective teaching of all students and help them reach their highest potential. This fact means that media and technology contribute to improving the quality of teaching in the classroom and generating students' best potential.

\section{CONCLUSION}

Based on data analysis, it can be concluded that online mathematics learning using the WhatsApp application during the Covid-19 was not effective in improving the learning outcomes of eighthgrade students of SMP Negeri 7 Kerinci. Based on the study's conclusions, the teachers must be more creative using the WhatsApp application on online mathematics learning.

\section{REFERENCES}

Afika, R. N., \& Pujiastuti, H. (2021). Efektivitas Pembelajaran Daring Matematika pada Masa Pandemi Covid-19 di Kota Cilegon [The Effectiveness of Mathematics Online Learning During the Covid-19 Pandemic in Cilegon City]. Journal of Holistic Mathematics Education, 5(1). 1-12.

Arsyad, A. (2011). Media Pembelajaran. Jakarta: PT. Raja Grafindo Persada.

Daheri, M., Juliana, J., Deriwanto, D., \& Amda, A. D. (2020). Efektifitas Whatsapp Sebagai Media Belajar Daring. Jurnal Basicedu, 4(4), 775-783.

Fajar, M., \& Larasati, A. I. (2022, January). Students' Perception Towards English Course in Asynchronous Online Learning Through Whatsapp During Covid-19 Pandemic. In 2nd International Conference on Education and Technology (ICETECH 2021) (pp. 391-398). Atlantis Press.

Handarini, O. I., \& Wulandari, S. S. (2020). Pembelajaran Daring Sebagai Upaya Study from Home (SFH) Selama Pandemi Covid-19. JPAP: Jurnal Pendidikan Administrasi Perkantoran, 8(3), 496-503. 
Mustakim. (2020). Efektivitas Pembelajaran Daring Menggunakan Media Online Selama Pandemi Covid-19 pada Mata Pelajaran Matematika. Al Asma: Journal of Islamic Education, 2(1), 1-12.

Oktavian, R., \& Aldya, R. F. (2020). Efektivitas Pembelajaran Daring Terintegrasi di Era Pendidikan 4.0. Didaktis: Jurnal Pendidikan dan Ilmu Pengetabuan, 20(2), 129-135.

Prajana, A. (2017). Pemanfaatan Aplikasi Whatsapp dalam Media Pembelajaran di UIN Ar-Raniry Banda Aceh. Jurnal Pendidikan Teknologi Informasi, 1(2), 122-133.

Riduwan. (2010). Metode dan Teknik Menyusun Tesis. Bandung: ALFABETA.

Riyanda, A. R., Herlina, K., \& Wicaksono, B.A. (2020). Evaluasi Implementasi System Pembelajaran Daring Fakultas Keguruan dan Ilmu Pendidikan (FKIP) Universitas Lampung. IKRA-TH Humaniora: Jurnal Sosial dan Humaniora, 4(1), 66-71.

Yaumi, M. (2018). Media dan Teknologi Pembelajaran. Jakarta: Prenada Media Group.

Zhafira, N. H., Ertika, Y., \& Chairiyaton. (2020). Persepsi Mahasiswa Terhadap Perkuliahan Daring Sebagai Sarana Pembelajaran Selama Masa Karantina Covid-19. Jurnal Bisnis dan Kajian Strategi Manajemen, 4(1), 37-45. 


\section{APPENDIX A}

\section{Online Mathematics Learning Questionnaire}

\begin{tabular}{|c|c|c|}
\hline No. & Item & Total Score \\
\hline 1. & I enjoy taking math learning online using WhatsApp. & 77 \\
\hline 2. & Math learning online using WhatsApp does not make me bored. & 77 \\
\hline 3. & $\begin{array}{l}\text { I am not entirely concentrated when math learning online using the } \\
\text { WhatsApp }\end{array}$ & 81 \\
\hline 4. & I do not understand math learning online using the WhatsApp & 70 \\
\hline 5. & I feel heavy with math learning online using the WhatsApp & 81 \\
\hline 6. & $\begin{array}{l}\text { I listened to the teacher's explanation seriously math learning online using the } \\
\text { WhatsApp }\end{array}$ & 78 \\
\hline 7. & $\begin{array}{l}\text { I took notes on the math material delivered by the teacher during math } \\
\text { learning online using the WhatsApp }\end{array}$ & 84 \\
\hline 8. & I studied independently before math learning online using WhatsApp started & 71 \\
\hline 9. & $\begin{array}{l}\text { When I do not understand math learning material, I will ask the teacher } \\
\text { directly online using Whats } A \text { ph. }\end{array}$ & 76 \\
\hline 10. & I do not master math material for math learning online using the WhatsApp & 74 \\
\hline 11. & $\begin{array}{l}\text { I am trying to get the best rank in class, although math learning online using } \\
\text { the WhatsApp }\end{array}$ & 75 \\
\hline 12. & I am trying to get a mark 100 math learning online using the WhatsApp & 85 \\
\hline 13. & $\begin{array}{l}\text { I fell bored with math learning online using WhatsApp just by giving notes } \\
\text { without any explanation from the teacher. }\end{array}$ & 74 \\
\hline 14. & $\begin{array}{l}\text { I feel lazy in doing the assignments given by the teacher during math learning } \\
\text { online using the WhatsApp }\end{array}$ & 79 \\
\hline 15. & $\begin{array}{l}\text { I remember the formulas in the math material even without asking the } \\
\text { teacher. }\end{array}$ & 77 \\
\hline 16. & $\begin{array}{l}\text { I have trouble with the network during math learning online using WhatsApp, } \\
\text { so I am often late in collecting assignments. }\end{array}$ & 85 \\
\hline 17. & $\begin{array}{l}\text { I assumed that my teacher would not mind if I followed the session math } \\
\text { learning online using WhatsApp. }\end{array}$ & 77 \\
\hline 18. & $\begin{array}{l}\text { I am working on exercise online using Whats } A p p \text {, just wasting my time for } \\
\text { free. }\end{array}$ & 77 \\
\hline 19. & $\begin{array}{l}\text { With math learning online using WhatsApp, I get the opportunity to study } \\
\text { anytime and anywhere. }\end{array}$ & 77 \\
\hline 20. & $\begin{array}{l}\text { With math learning online using WhatsApp, I discovered new knowledge } \\
\text { from classroom learning that I had not learned. }\end{array}$ & 77 \\
\hline 21. & $\begin{array}{l}\text { I study math hard though math learning online using WhatsApp makes me } \\
\text { feel uncomfortable. }\end{array}$ & 85 \\
\hline 22. & I have got learning resources during math learning online using WhatsApp. & 75 \\
\hline 23. & $\begin{array}{l}\text { Math learning online using WhatsApp is held only to get added value from the } \\
\text { teacher. }\end{array}$ & 77 \\
\hline 24. & $\begin{array}{l}\text { I make my math notes from the material given by the teacher during math } \\
\text { learning online using WhatsApp. }\end{array}$ & 87 \\
\hline 25. & I get high marks if I diligently follow math learning online using WhatsApp. & 82 \\
\hline
\end{tabular}

